ОБҐРУНТУВАННЯ ЗМІСТУ ПОНЯТТЯ «ПРОФЕСІЙНА КУЛЬТУРА» МАЙБУТНЬОГО ФАХІВЦЯ 3 ВІЙСЬКОВОЇ ЮСТИЦІї

\title{
GROUNDING FOR THE CONCEPT OF "PROFESSIONAL CULTURE" OF THE FUTURE SPECIALIST IN MILITARY JURISDICTION
}

Стаття присвячена питанням формування просресійної культури майбутніх фрахівців із військової юстиції. у статті розглянуто зміст та складники поняття «професійна культура» майбутніх орахівців із військовоі юстичії в контексті їх професійної діяльHOCmi.

Метою статmі $є$ визначення змісту та складників поняття «профресійна культура» майбутніх фрахівців із військової юстиції в контексті їх професійної діяльності.

Конкретизовано зміст поняття «військова юстичія» та визначено напрями ії діяльності: підтримання правопорядку серед військовослужбовців і контроль за їх статутною поведінкою; дізнавальна діяльність щодо вчинення військовослужбовцями правопорушень; юридично-консультативна або юридично-роз'яснювальна робота у військових підрозділах; розслідування кримінальних правопорушень і пред'явлення військовослужбовцям обвинувачення у вчиненні злочину; розгляд справ про обвинувачення військовослужбовців у вчиненні злочину або інших справ щодо розв'язування спірних правовідносин, в яких стороною є військовослужбовець, здійснюється військовими (або цивільними) судами або суддями, які спеціалізуються у сорері військових злочинів.

Встановлено, що фрахівець із військової юстиції - це військовий фахівець юридичного профрілю, який володіє теоретико-правовими знаннями з військових, військово-юридичних та юридичних навчальних дисциплін, практичними навичками правової роботи, спрямованої на правильне застосування, неухильне дотримання вимог законодав ства у військовому підрозділі, надання командуванню пропозицій та консультацій щодо вирішення питань правового забезпечення діяльності у військах (силах) та підрозділах Збройних сил України. Відповідно до чинного законодавства визначено просесійні обов'язки зазначених фрахівців. На підставі огляду літератури розкрито особливості просресійної діяльності юриста.

Висвітлено різні наукові підходи до визначення поняття «профресійна культура» фахівців юридичної галузі. Обгрунтовано i виокремлено в структурі профресійної культури юриста такі складники: правова, психологічна, комунікативна, професійноетична; розкрито їх зміст.

Запропоновано визначення сутності поняття «професійна культура» фрахівців із військової юстиції як складного особистісного утворення, що поєднує сукупність стійких знань про цінності, правила, норми, принципи юридичної діяльності, передбачає сорормованість професійно-етичних цінностей та розвиток професійно важливих якостей (моральних, вольових, комунікативних та ін.) якостей, що забезпечують ефективне виконання професійних функцій із метою дотримання і захисту прав і свобод людини, загальних інтересів суспільства та держави.

Ключові слова: юристи, військова юсти чія, срахівці з військової юстичії, професійна культура юриста, складники професійної культури юриста.

The article deals with the issues of developing the professional culture of future specialists in the sphere of military jurisdiction. The article describes the meaning and the components of the concept of "professional culture" of future specialists in military jurisdiction under their profession

The article is aiming to determine the meaning and the components of the concept "professional culture" of the future specialists in military jurisdiction within their professional activity. The meaning of the concept "professional culture" is specified and the field of its implementation is determined as follows: maintaining of law and order among the military personnel, control over the military regulations compliance; investigation of the offences committed by the military staff; consulting and explaining of legal issues within military units; investigation of crimes and charges of crimes against soldiers; studying the cases of indictments against military personnel of crimes or other arguable legal issues concerning the soldiers, appearing before the military (or civil) courts or judges specialized in war crimes.

The specialist in the field of military jurisdiction is determined as a military person who is an expert in military law theory, military jurisdiction and legal disciplines, who has practical experience in legal activity aiming at correct implementation and full compliance with the legislative norms in a military unit, who can provide the command with proposals and advice in legal issues concerning the activity of units and divisions of the Armed Forces of Ukraine. The job duties and responsibilities of above specialists are determined according to the current legislation. Based on the review of literary sources, the specific character of legal specialist's job is described.

The different approaches to the definition of the term "professional culture" of legal specialists are highlighted. The following components of the professional culture of the legal specialists are specified and singled out: legislative, psychological, communicative, professional ethics; the meaning of each component is explained.

Key words: professional culture, military jurisdiction, legislative norms, legal specialists.
Постановка проблеми у загальному вигляді. Становлення і розвиток України як демократичної держави, перспективи входження ії̈ у світове співтовариство вимагає оновлених підходів до про- блем фрормування особистості у всіх ланках суспільного життя, зокрема, в освітній галузі. Перш за все, має бути вдосконаленою система профресійної підготовки студентів-юристів, оскільки вони 
через сферу майбутньої професійної діяльності впливатимуть на формування України як правової держави. Адже призначення профеесійної діяльності юриста - це захист прав, свобод та законних інтересів фрізичних та юридичних осіб, надання їм компетентної та висококвалісрікованої допомоги, а також їх представництво на належному фраховому рівні перед іншими суб'єктами. Це зумовлює необхідність наукового дослідження та обґрунтування сутності, педагогічних умов фрормування професійної культури майбутніх юристів військової галузі.

Високий рівень професійної культури майбутніх юристів військової галузі - необхідна вимога сучасності, адже від її ссрормованості у представників юридичного фраху залежить результат державотворчих процесів в Україні, можливість здійснення демократичних перетворень в українському суспільстві. 3 огляду на такий стан справ, актуальною $є$ проблема формування професійної культури майбутніх юристів військової галузі під час здобуття освіти.

Аналіз останніх досліджень і публікацій. Вивчення сучасної педагогічної літератури, дисертаційних досліджень свідчить про посилену увагу науковців до проблеми формування професійної культури майбутніх фрахівців. Педагогічний аспект професійної культури представлено у дослідженнях І. Беха, Г. Васяновича, В. Гриньової, І. Зязюна, В. Кременя, О. Отич, І. Пальшкової, Ю. Чернової та ін. Окремі аспекти фрормування професійної культури та особливості її фрормування в представників правоохоронних органів та військовослужбовців розкрито в працях О. Кравченко, І. Михайліченко, В. Молдавчук, Н. Самандас, С. Сливки, О. Тогочинського, О. Федоренко, С. Шумовецької та ін. Учені підкреслюють, що профресійна культура $\epsilon$ важливою передумовою належного становлення фрахівця, його ефективної професійної діяльності.

Виділення не вирішених раніше частин загальної проблеми. Успіх професійної діяльності представників багатьох професій, зокрема юристів будь-якої галузі, залежить від рівня їхньої професійної культури. Аналізуючи сучасну теорію і практику професійної підготовки майбутніх юристів, можна стверджувати, що ще мало вивчено та розроблено теоретичні засади соормування профресійної культури майбутніх юристів військової галузі у процесі їх профресійної підготовки. $€$ нагальна потреба в опрацюванні і поширенні результатів відповідних досліджень і досвіду з цього напряму в університетській освіті, об'єктивній оцінці пропонованих технологій навчання і вивченні можливих шляхів удосконалення якості професійної підготовки майбутніх юристів військової галузі.

Отже, натепер одним 3 основних завдань вищої юридичної освіти, поряд із фрормуванням профресійно компетентного фахівця $€$ завдання фрормування їхньої профресійної культури ще під час здобуття освіти. Отже, проблема фрормування профресійної культури майбутніх фрахівців із військової юстиції залишається мало дослідженою, а також відсутнє чітке визначення поняття «професійна культура» майбутніх фрахівців із військової юстиції.

Мета статті - визначити зміст та складники поняття «професійна культура» майбутніх фрахівців із військової юстиції в контексті їхньої профресійної діяльності.

Виклад основного матеріалу. Сфрерою професійних обов'язків юриста $€$ забезпечення існування та фрункціонування правової системи держави. Право, регулюючи правові відносини в суспільстві, забезпечує правовий порядок i організованість у визначених законами ссрерах життя. Юристи незалежно від галузі, в якій вони працюють, під час виконання своїх професійних обов'язків беруть участь в організації та впорядкуванні відносин між державою і громадянами, між організаціями і підприємствами, між членами суспільства в процесі розв'язання їх проблем, які часто мають складний і суперечливий характер.

Розглянемо особливості професійної діяльності юриста військового підрозділу (бригади), а саме фрахівця з військової юстиції.

Розглядаючи зміст поняття «військова юстиція», доцільно розглянути його складові частини. Основою системи військової юстиції $є$ сукупність законодавства у ссрері військової діяльності, система державних органів, які уповноважені здійснювати правозастосування в цій сфері та дотримання дисципліни, що необхідна усім збройним силам не лише для забезпечення ефективного та надійного виконання покладених на них завдань. Традиційно до органів військової юстиції зараховують військові суди, військову прокуратуру та юридичну службу військових формувань.

В. Шишкін зазначає, що під військовою юстицією розуміється кілька напрямів предметної діяльності, які здійснюються (можуть здійснюватися) різними інституціями та органами: 1) підтримання правопорядку серед військовослужбовців i контроль за їхньою статутною поведінкою у громадському середовищі; 2) дізнавальна діяльність щодо вчинення військовослужбовцями правопорушень; 3) юридично-консультативна або юридичнороз'яснювальна робота у військових підрозділах; 4) розслідування кримінальних правопорушень і пред'явлення військовослужбовцям обвинувачення у вчиненні злочину здійснюється військовими чи спеціальними прокурорами або командирами військових частин; 5) розгляд справ про обвинувачення військовослужбовців у вчиненні злочину або інших справ щодо розв'язування спірних правовідносин, в яких стороною $є$ військовослужбовець, здійснюється військовими (як свідчить 
сучасна практика) і цивільними судами або суддями, які спеціалізуються у сфері військових злочинів [7].

Тобто фрахівець із військової юстиції - це військовий фрахівець юридичного профрілю, який володіє теоретико-правовими знаннями з військових, військово-юридичних та юридичних навчальних дисциплін, практичними навичками правової роботи, спрямованої на правильне застосування, неухильне дотримання вимог законодавства у військовому підрозділі, надання командуванню пропозицій та консультацій щодо вирішення питань правового забезпечення діяльності у військах (силах) та підрозділах Збройних сил України.

Відповідно до Закону України «Про Статут внутрішньої служби Збройних сил України» від 24 березня 1999 р. № 548-XIV (ст.ст. 99, 100) юрист військового підрозділу (фахівець із військової юстиції) в мирний і воєнний час відповідає за організацію і стан правової роботи в підрозділі (бригаді), а саме: організовує правову роботу, спрямовану на правильне застосування, неухильне додержання вимог законодавства в підрозділі; перевіряє відповідність вимогам законодавства проєкти наказів, інших документів правового характеру, що подаються погодження відповідним службовим особам; надає письмовий висновок командиру підрозділу з роз'ясненням та пропозиціями щодо юридично обґрунтованого вирішення відповідних питань у разі невідповідності проєкту наказу чи іншого документа правового характеру вимогам законодавства; здійснює правове забезпечення господарської діяльності підрозділ; організовує претензійну роботу, готує позови та скарги до суду; за дорученням командира підрозділу представляє інтереси бригади в судах та інших органах; аналізує наслідки розгляду претензій, позовів та справ у судах і подає командирові пропозиції щодо вдосконалення правового забезпечення діяльності військового підрозділу; надає правову допомогу під час розслідувань правопорушень, які були скоєні військовослужбовцями; надає правову оцінку фактам порушень військової та трудової дисципліни в підрозділі; надає правову допомогу службовим особам підрозділу в дотриманні законодавства з питань соціального і правового захисту військовослужбовців, членів їхніх сімей та працівників бригади; організовує та проводить заходи з правової підготовки та бере участь у правовому вихованні особового складу військового підрозділу, правовому інфрормуванні особового складу, надає консультації з питань, пов'язаних із діяльністю підрозділу [2].

Як свідчать дослідження І. Івашкевич, Н. Кожем'яко, О. Кравченко, Б. Левківського та ін., основними особливостями професійної діяльності юриста є: правова регламентація (нормативність) професійної поведінки, ухвалюваних рішень працівників правоохоронних органів, юридичних служб та інших юристів, що професійно беруть участь у правовій діяльності; владний, обов'язковий характер професійних повноважень посадових осіб; екстремальний характер діяльності багатьох юристів, особливо тих, хто працює в органах суду, прокуратури, податкової служби і податкової поліції і т.п.; нестандартний, творчий характер праці юриста; процесуальна самостійність, персональна (для багатьох - підвищена) відповідальність юристів, що працюють у правоохоронних органах, державно-правових структурах.

Як зазначає К. Радченко, у військовій прокуратурі юристи займаються розслідуванням кримінальних справ, здійснюють нагляд за прикордонними військами, військами МВС, стежать за дотриманням законності у всіх організаціях, що мають військові фрормування. В арміях зарубіжних країн робота фахівців із військової юстиції (військових юристів) полягає у правовому забезпеченні діяльності відповідних органів військового управління, розслідування, обвинувачення і захисту осіб, обвинувачених у злочинах, скоєних в армії, включаючи вбивства, державну зраду і тероризм, а також нормотворчої діяльності [3].

На думку І. Івашкевич, Н. Кожем'яко, В. Омеляненко, професійна культура юриста проявляється і пов'язана із знаннями законодавства і можливостей юридичної науки, переконаністю в необхідності і соціальній корисності законів і підзаконних актів, умінням користуватися правовим інструментарієм - законами та іншими правовими актами в повсякденній діяльності, вдаватися до використання всіх досягнень юридичної науки і практики при прийнятті і оорормленні рішень.

Разом із тим, як зазначають О. Скакун, С. Сливка, кожна юридична профресія має свою специоріку, що зумовлює й особливості професійної культури різних її представників (суддів, прокурорських працівників, співробітників органів внутрішніх справ, юрисконсультів, адвокатів тощо).

Огляд психолого-педагогічної літератури та інформаційних джерел, присвячених цій проблемі, свідчить, що можна виділити кілька підходів до визначення поняття «професійна культура».

Поняття «профресійна культура» набуло широкого вжитку у вітчизняній педагогіці 80-х рр. XX ст., що пов'язано з розробкою культурологічного підходу, з позицій якого розглядалось багато педагогічних процесів і явищ. Так, формування професійної культури розглядалося як системоутворюючий чинник становлення майбутнього фрахівця.

Суть профресійної культури на особистісному рівні, як зазначають Н. Кузьмина, А. Реан, виражається мірою оволодіння необхідних професійних знань, навичок й умінь, професійного досвіду, ступенем інтеграції профресійних і соціальних якостей 
особистості; здатністю застосовувати сукупність найбільш раціональних способів, прийомів роботи в різних ситуаціях, що складаються в процесі діяльності й забезпечують її високу ефективність. У реальному функціонуванні професійна культура особистості виступає, насамперед, як володіння фрахівцем сукупністю конкретних соціально значущих профресійних дій [1].

Аналіз наукової літератури (О. Скакун, Н. Овчаренко) свідчить, що професійна культура розглядається як вищий рівень підготовленості фрахівців, що інтегрує в собі інфрормаційну поінфрормованість про професійну діяльність, психологічну готовність до їі виконання, і технологічні вміння вирішувати профресійні завдання. Інтегруючою основою для вказаних рівнів підготовленості фахівців виступає ціннісно-смислова складова частина профресійної культури як відбиття суті культури особистості фрахівця з їі ціннісно-регулятивною функцією. Профресійна культура фрахівця функціонально визначає зміст і спосіб існування фрахівця в предметно-профресійному середовищі відповідно до соціальної спрямованості профресійної праці й способів її перетворення за функціональним призначенням профресії [4].

Профресійна культура, на думку С. Сливки, «сукупність способів і технологій певної професійної діяльності, що визнані суспільством еталоном для цієї діяльності, а з іншого боку, сукупність засвоєних, усвідомлених людиною способів цієї діяльності» [5, с. 123].

С. Шумовецька визначає профресійну культуру фрахівця як інтегративне системне утворення, що характеризує спосіб його професійної діяльності, охоплює сукупність ціннісних орієнтацій, світоглядних та спеціальних знань, якостей, умінь, навичок, визначає профресійний тип мислення, поведінку в профресійному середовищі, профресійні моделі взаємодії і спілкування [7]. У структурі професійної культури майбутнього фрахівця автор виділяє ціннісний, пізнавальний, комунікативний, діяльнісний та професійно-особистісний компоненти.

Термін «профресійна культура» підкреслює, що культура розглядається щодо специфічної якості діяльності фрахівця і розкриває предметний зміст культури, що визначається специфікою професії, професійної діяльності і профресійного товариства. Це підтверджує і визначення поняття, яке наведено в енциклопедії професійної освіти. Профресійна культура визначається як: 1) цілісна, складно ієрархічна система профресійної структури особистості, що складається і фрункціонує у взаємодії двох фрорм: об'єктивної (мобікультурні об'єкти та реалії) та суб'єктивної (відбиток культури у свідомості); 2) специфічна сукупність засобів, способів, фрорм, зразків і орієнтирів взаємодії людей у профресійному середовищі, які вони виробляють у сумісній професійній діяльності; 3) сис- тема колективних цінностей, переконань, зразків і норм виробничої поведінки, притаманних певній групі працівників - професіоналів. Профресійна культура фрормується як важливий механізм взаємодії, що допомагає людям жити в професійному середовищі, зберігати єдність і цілісність науковопрактичної діяльності [8].

Досліджуючи профресійну культуру майбутніх бакалаврів із правознавства, В. Омельяненко розглядає її як динамічне, розвивальне утворення, що інтегрує сукупність стійких знань, практичних умінь, морально-етичних якостей, ціннісних орієнтацій, наявність актуалізованої здатності приймати раціональні рішення, надаючи правові послуги, відповідно до чинного законодавства й нести соціально-моральну відповідальність за їх реалізацію на рівні тріади: «правник - суспільство - етика».

Отже, професійна культура юриста передбачає закономірне дотримання юристом узвичаєних норм і принципів моралі в процесі виконання службових обов'язків, їх впровадження в юридичну практику. При цьому профресійна культура юриста містить прояв норм моралі в стосунках: «юрист клієнт», «юрист - підслідний», «юрист - потерпілий», «юрист - свідок», «юрист - колега» та ін.

Профресійна культура майбутнього фрахівця характеризує його як суб'єкта діяльності у сорері вибраної профресії. Тому слушним $є$ підхід С. Сливки до визначення сутності профресійної культури, який розглядає професійну культуру і як науку, і як професійну властивість юриста [5, с. 8]. Профресійна культура юриста, на думку вченого, як комплексна практико-прикладна юридична наука містить, по-перше, систему знань про певні елементи різних видів культур, які необхідні юристові у його професійній діяльності, зокрема, вчення про правову, політичну, педагогічну, естетичну, психологічну культуру тощо, по-друге, правничу деонтологію як систему знань про фрормування почуття службового юридичного обов'язку, по-третє, правничу етику як вчення про професійну поведінку юриста з точки зору морально-етичних вимог.

Профресійна культура юриста, як його властивість, на переконання С. Сливки, передбачає знання правових, моральних, естетичних, педагогічних, психологічних норм, повагу до права, моральні принципи і норми, почуття службового юридичного обов'язку, вміння і навички реалізовувати вказані норми та правила, готовність виконувати свій службовий обов'язок, діяти правомірно в будь-якій ситуації, саме правомірну поведінку юриста при здійсненні ним професійної діяльності [5, с. 12].

У науковій літературі $є$ різні підходи до визначення сутності та змісту профресійної культури. Так, О. Скакун виокремлює такі елементи професійної культури правника, як правова, політична, психологічна, етична, естетична, екологічна, економічна, 
інформаційна культура [4, с. 219]. С. Гусарєв, О. Тихомиров виокремлюють моральну, етичну, С. Сливка - духовну, моральну, естетичну, національну, педагогічну, політичну, економічну, акторську культуру.

Обґрунтовуючи суть профресійної культури майбутніх юристів, Б. Чупринський вирізняє в її структурі такі взаємозалежні підструктури: професійнодеонтологічна (знання й уміння реалізовувати в повсякденній трудовій діяльності норми й правила взаємин, взаємодії в індивідуально-діловій комунікації, система професійних ідеалів і цінностей тощо); комунікативно-перцептивна (вміння адекватно розуміти почуття, емоційний стан партнера із спілкування; уміння слухати, демонструвати розуміння змісту висловлень контактора; уміння налагоджувати «зворотний зв'язок» із партнерами в ситуації індивідуально-ділової комунікації тощо); інтерактивно-практична (володіння основами психолінгвістики, соціолінгвістики; адекватне використання спеціально-професійних, психолого-педагогічних знань; правильна побудова монологічної й діалогічної, усної й писемної мови; уміння адекватно визначити професійно-мовну тактику в ситуаціях співробітництва й конкуренції; уміння управляти індивідуальним і діловим спілкуванням тощо); профресійно-акмеологічна (уміння здійснювати аналіз самоаналіз проявів професійно-етичної культури в ситуаціях юридичної діяльності, адекватно оцінювати «сильні» й «слабкі» сторони професійної поведінки, усвідомлення необхідності самокорекції недоліків тощо) [6, с. 10].

Дотримуючись позиції О. Скакун щодо розуміння професійної культури юриста як сукупності різних елементів культур та норм-вимог правового, психологічного, етичного, естетичного, політичного, економічного, екологічного та інфрормаційного характеру, які висуваються до фрахівця для забезпечення ефективного виконання профресійних фрункцій, можна виокремити у структурі професійної культури фрахівця військової юстиції як юриста такі складники: правова, психологічна, комунікативна та професійно-етична культура.

Важливим елементом його професійної культури є правова культура, яка є системою професійно-правових знань, умінь і навичок, що характеризують ступінь правового розвитку фахівця і її вплив на правову культуру суспільства в процесі юридичної діяльності [4, с. 219].

Правова культура майбутніх фрахівців поєднує в собі правові знання, погляди й установки особистості, а також правову активність, уміння та навички оцінювати свої та чужі дії з точки зору чинних законів, вибирати і використовувати їх для досягнення поставлених цілей у законний спосіб.

На наш погляд, основу правової культури юриста становлять: фрахові юридичні знання, уміння і навички; знання зі сфер життєдіяльності людини, пов'язаних із відповідною галуззю правового регулювання; правова свідомість та правомірна поведінка носія цієї професії.

Важливу роль відіграє психологічна культура як одна із складових частин професійної культури юриста. Так, С. Сливка під психологічною культурою цієї категорії фрахівців розуміє рівень володіння ними психологічними знаннями, уміннями, навичками і прийомами і використання їх у профресійній діяльності [5].

У процесі професійної діяльності юристам незалежно від їх спеціалізації постійно доводиться спілкуватися з різними людьми, досягати 3 ними порозуміння, підтримувати на належному рівні психологічний контакт, надаючи в необхідних випадках спрямовуючий вплив на розвиток комунікативних процесів. Тому особливе місце, з погляду окремих авторів, у структурі профресійної культури займає комунікативна культура.

С. Сливка підкреслює, що професійно-етична культура юриста - це складне індивідуально-психологічне утворення, що об'єднує теоретичні знання 3 професійної етики та професійні практичні вміння юриста, що забезпечують вибір ним свідомої етичної поведінки відповідно до професійноетичних норм [5].

Серед фрункцій професійно-етичної культури юриста найбільш важливими є: створення професійно-етичних цінностей і процесу засвоєння цих цінностей; вироблення поваги до права; створення механізму правомірної поведінки при здійсненні профресійних повноважень; фрормування рівня усвідомлення власних моральних помилок і шляхів їх виправлення, розуміння природних прав людини та ціни їі життя; запобігання порушенню гармонії між духовним і матеріальним, віддача всіх сил, здібностей, таланту, енергії для виконання службових обов'язків [5].

Висновки. Отже, враховуючи сутність та особливості професійної діяльності юриста військового підрозділу (бригади), поняття «професійна культура» фрахівців із військової юстиції ми визначаємо як складне особистісне утворення, що поєднує сукупність стійких знань про цінності, правила, норми, принципи юридичної діяльності, передбачає сорормованість профресійно-етичних цінностей та розвиток професійно важливих якостей (моральних, вольових, комунікативних та ін.) якостей, що забезпечують ефективне виконання професійних функцій із метою дотримання і захисту прав і свобод людини, загальних інтересів суспільства та держави.

Враховуючи складність представленого френомена «професійна культура» фрахівців із військової юстиції, доцільно підкреслити, що його формування передбачає створення певних педагогічних умов в освітньому середовищі вищого військового навчального закладу. 
БІБЛІОГРАФІЧНИЙ СПИСОК:

1. Кузьмина Н.В., Реан А.А. Профессионализм педагогической деятельности. Санкт-Петербург : С.-ПбГУ, 1993. 63 с.

2. Про Статут внутрішньої служби Збройних сил України : Закон України від 24 березня 1999 р. № 548XIV. Ст. 99; 100.

3. Радченко К.М. Педагогічні умови фрормування профресійної компетентності майбутніх військових юристів у процесі фрахової підготовки : дис. ... канд. пед. наук : 13.00.04. Харків : УІПА, 2018. 336 с.

4. Скакун О.Ф. Юридична деонтологія : підручник. Харків : Еспада, 2008. 400 с.

5. Сливка С.С. Профресійна культура юриста (теоретико-методологічний аспект) : монографрія. Львів : Асріша, 2000. 336 c.
6. Чупринський Б.О. Формування профресійної культури майбутніх юристів: фрілософрсько-правове дослідження : дис. ... канд. юр. наук : 12.00.12 / Львів. держ. ун-т внутр. справ. Львів, 2010. 180 с.

7. Шишкін В. Військові суди через призму правової держави. Право України. 2004. № 4. С. 107-110.

8. Шумовецька С.П. Сутність, структура й особливості змісту профресійної культури офріцера-прикордонника. Наукові записки Вінницького державного педагогічного університету імені Михайла Коцюбинського. Серія: Педагогіка і психологія : збірник наук. пр. Вінниця : Нілан ЛТД, 2019. Вип. 60. C. 105-110.

9. Энциклопедия профессионального образования : в 3-х т. Т. 2 / под ред. С.Я. Батышева. Москва : АПО, 1998. С. 124-125. 